Ольга Красницька, кандидат педагогічних наук Національний університет оборони України імені Івана Черняховського ORCID ID 0000-0002-0417-3318

\title{
ТЕОРЕТИКО-МЕТОДОЛОГІЧНІ ОСНОВИ ПЕДАГОГІЧНОЇ ДІЯЛЬНОСТІ ВИКЛАДАЧА ВИЩОГО ВІЙСЬКОВОГО НАВЧАЛЬНОГО ЗАКЛАДУ
}

У статті розглянуто теоретико-методологічні основи педагогічної діяльності викладача вищого військового навчального закладу. Окреслено історичний аспект педагогічної діяльності. Показано специфіку вищого військового навчального закладу. Обгрунтовано поняття «педагогічна діяльність викладача вищого військового навчального закладу». Розкрито структурні компоненти педагогічної діяльності, напрями діяльності викладача ВВНЗ. Визначено рівні готовності викладача ВВНЗ до педагогічної діяльності (репродуктивний, конструктивний, творчий), а також рівні їі продуктивності (мінімальний, нормативний, еталонний). Виявлено й описано передумови успішності педагогічної діяльності.

Ключові слова: педагогічна діяльність; викладач ВВНЗ; педагогічна діяльність викладача ВВН3; успішність педагогічної діяльності; педагогічні здібності; педагогічна спрямованість; професійна компетентність; особистісні якості.

Постановка проблеми. Тисячі професій народжуються і вмирають. Але серед них є одна вічна, що посідає особливе місце. Це професія вчителя вихователя, викладача, педагога. Педагог забезпечує підготовку підростаючого покоління до життя, виконання соціальних ролей у суспільстві, створює умови для розвитку і становлення особистості молодої людини, іiї самоствердження та самореалізації.

Педагогічна діяльність викладача вищого військового навчального закладу відзначається підготовкою курсантів та офіцерів для подальшої служби у військах, розвитку Збройних Сил України й забезпечення обороноздатності держави. Розвиток української державності, сучасні події на теренах нашої країни вимагають змін у професійній підготовці військових фахівців. Отже, й педагогічна діяльність науково-педагогічних та наукових працівників ВВНЗ та ВНП ВНЗ має відповідати запитам часу суспільства.

Аналіз останніх досліджень і публікацій. Проблеми педагогічної діяльності викладача вищого навчального закладу досліджували І. Бартєнєва, В. Богословський, Г. Васянович, Т. Іванова, 3. Єсарьова, Н. Кузьміна, А. Кузмінський, 3. Курлянд, Т. Леонтьєва, А. Марушкевич, Г. Мешко, О. Мороз, В. Ортинський, В. Рибалка, О. Романовський, В. Сластьонін, М. Фіцула, Т. Туркот, О. Щербаков тощо. Діяльністю викладачів вищих військових навчальних закладів займалися А. Вітченко, В. Семиченко, В. Ягупов. 
Мета статті - розкрити теоретико-методологічні основи педагогічної діяльності викладача вищого військового навчального закладу.

Методи дослідження: аналіз, синтез, порівняння і систематизація наукових джерел.

Виклад основного матеріалу. Практика навчання й виховання своїм корінням сягає глибинних шарів людської цивілізації. 3'явилася вона разом із першими людьми. Потреба в ній була обумовлена необхідністю зберегти рід. Тому дитину 3 ранніх років долучали до трудової діяльності. Так вона засвоювала необхідні знання, уміння, навички, норми поведінки. Таким чином, передача досвіду відбувалася як природний для людського існування процес: від дорослого - дитині.

Поступово накопичувалися знання, розширювався життєвий досвід, змінювалися умови життя, з'являлися нові форми праці. Але на певному етапі розвитку людства було зібрано обсяг досвіду, неможливого вже для засвоєння в ході природного існування, тому виникла потреба у спеціалізованому навчанні та вихованні. Передача дорослими дитині знань про навколишній світ, навчання необхідним для подальшого життя умінням стала справою найбільш мудрих і досвідчених людей - майстрів, які володіли певними секретами й таємницями. Так власне й виникла педагогічна діяльність і професія вчителя.

У Давньому Шумері, Вавилоні, Сгипті, Ассирії, Фінікії вчителями були переважно жерці, які становили привілейовану касту. У Древній Греції вільнонаймані громадяни, яких називали граматистами, педономами, дидаскалами або педотрибами. У Стародавньому Римі вчителями ставали державні чиновники, добре обізнані в науках, які багато подорожували, володіли кількома мовами, знали культуру і звичаї інших народів.

У середньовіччі - духовні особи - священики, монахи, поведінка, статус, методи роботи яких диктувалися релігійними канонами. Хоча дещо пізніше в містах їх обов'язки могли виконувати й наймані особи. У середньовічних міських школах, університетах педагогами дедалі частіше ставали люди, які здобували спеціальну освіту [2]. У Київській Русі вчителів називали майстрами, підкреслюючи у такий спосіб глибину поваги до тих, хто творить духовне багатство суспільства.

Бурхливого розквіту освіта здобула в епоху Відродження, коли розширилася мережа протестантських шкіл, а в Україні з'явилися всім відомі братські школи. Серед їх учителів були такі, які згодом стали знаними далеко за межами нашої держави (Стефан і Лаврентій Зизанії, Іов Борецький, Кирило Ставровецький Транквіліан, Павло Беринда, Слисей Плетенецький) [5].

Таким чином, педагогічна професія існує у світі вже не перше тисячоліття, учитель завжди вважався високоповажною й найбільш мудрою та досвідченою людиною, яка акумулює всі знання, науку й мудрість світу. Він відповідав за навчання та виховання підростаючого покоління, створення умов для повноцінного розвитку особистості, іiі самореалізації. Тому до 
нього, Звичайно, висуваються високі вимоги як до особистості, так i професіонала у своїй справі. Навіть іншою професією можна оволодіти тільки через педагогічну діяльність учителя і викладача.

Педагогічна діяльність у вищому навчальному закладі, як зазначає М. Фіцула, має надзвичайно важливе соціальне значення, оскільки йдеться про формування майбутнього фахівця, від рівня підготовленості якого значною мірою залежить економічний, політичний, соціальний, культурний розвиток суспільства.

Одним із різновидів ВНЗ є вищчй військовий навчальний заклад, що являє собою вищий навчальний заклад державної форми власності, який здійснює на певних рівнях вищої освіти підготовку, перепідготовку та підвищення кваліфікації військових фахівців для подальшої служби на посадах офіцерського (сержантського, старшинського) або начальницького складу з метою задоволення потреб Збройних Сил України, інших утворених відповідно до законів України військових формувань, проводить наукову, науково-технічну, інноваційну та/або методичну діяльність [6].

Педагогічну діяльність викладача вищого військового навчального закладу ми визначаємо як вид творчої професійної діяльності, спрямованої на підготовку, перепідготовку та підвищення кваліфікації компетентного військового фахівця (професіонала), здатного до саморозвитку й самовдосконалення, спроможного зайняти та відстоювати активну життєву i професійну позицію, включитися в соціальну, духовну та інші сфери життя суспільства, здібного до розвитку обороноздатності держави. Її здійснюють науково-педагогічні, наукові та педагогічні працівники 3 числа військовослужбовців і працівників Збройних Сил України.

У ВВНЗ навчаються курсанти (студенти) та слухачі, які мають досвід проходження служби на різних посадах у військах, наукові ступені та роки професійної діяльності. Тому до особистості викладача ВВНЗ висуваються підвищені вимоги. Він має володіти педагогічною спрямованістю, високим рівнем професійних знань, розвинутими педагогічними здібностями та вміннями, бездоганною педагогічною технікою та професійно важливими якостями, педагогічною етикою та культурою, а також повинен мати сформований позитивний педагогічний імідж, прагнути до здобуття авторитету й постійного самовдосконалення.

Ефективне здійснення педагогічної діяльності вимагає від викладача чіткого розуміння іï структурних компонентів. Оскільки для досягнення результатів необхідно правильно поставити цілі, визначити завдання й підібрати зміст, методи, форми взаємодії зі слухачами (курсантами, студентами), то доречно виділити такі компоненти, як: цільовий, змістовий, технологічний, результативний.

Цільовий компонент передбачає: постановку цілей як стратегічних (наприклад, усесторонній розвиток особистості), так і конкретних - на певний період часу, для кожного військовослужбовця зокрема, залежно від напряму діяльності тощо; визначення завдань, поетапне вирішення яких 
сприятиме досягненню мети; планування системи роботи; проектування навчальних занять; прогнозування результатів освітнього процесу.

Змістовий компонент відображає зміст, вкладений як у мету, так і в кожну конкретну задачу [4], зокрема, коли педагог, аналізуючи різноманітну науково-методичну літературу, результати наукових досліджень, емпіричні дані, підбирає найбільш актуальну й корисну інформацію, яку зможе передати слухачеві у процесі навчальних занять, сформувати в них певні уміння і навички, розвинути здібності.

Технологічний компонент охоплює взаємодію викладача та слухача (курсанта, студента), їх співпрацю, організацію й управління діяльністю військовослужбовця, їі активізацію, організацію самостійної роботи. Містить підбір форм, методів, прийомів, засобів навчання i виховання, стилю взаємодії, стилю спілкування, стилю керівництва.

Результативний компонент відображає ефективність діяльності педагога, передбачає аналіз й оцінювання ним досягнутих у процесі навчально-виховної роботи результатів, установлення відповідності поставленій меті та завданням, виявлення недоліків та їх причин [4], а також своєчасне внесення коректив. Має відповідати цільовому компоненту.

Для ефективного здійснення педагогічної діяльності, правильного розподілу викладачу своїх зусиль, орієнтування на певні результати, постановку цілей і завдань варто проаналізувати основні напрями діяльності викладача BВН3, серед яких: навчальна, методична, наукова, організаційна (організаційно-методична, виховна, спортивна, міжнародна) робота.

Навчальна діяльність передбачає організацію освітнього процесу шляхом проведення навчальних занять. Основними їх видами (формами навчання) відповідно до нормативних документів у вищій військовій школі $є$ такі, як: лекція, групове, семінарське, практичне, лабораторне заняття, групова вправа, воєнна (воєнно-спеціальна) гра, консультація, залік, іспит, тактичні (тактико-спеціальні, тактико-стройові) заняття, захист курсової/дипломної/магістерської роботи, індивідуальне заняття, командноштабні навчання, самостійна робота. Також викладач здійснює керівництво курсовими, дипломними, магістерськими роботами, їх рецензування, керівництво навчальною та іншими видами практик i військовим (флотським) стажуванням, перевірку розрахунково-графічних робіт, рефератів, контрольних робіт, рецензування рефератів вступників до ад'юнктури, керівництво ад'юнктами, наукове консультування докторантів.

Методична робота реалізується через підготовку до навчального процесу, а саме: підготовку до всіх видів навчальних занять; розробку i підготовку до видання конспектів лекцій, навчальних i навчальнометодичних посібників, підручників, практикумів, збірників воєнних (воєнно-спеціальних) ігор, методичних рекомендацій, збірників вправ і задач, інструкцій; написання методичних розробок, планів занять, завдань для самостійної роботи слухачів (курсантів), тестових завдань, екзаменаційних білетів; підготовку наочних навчальних матеріалів; розробку тем курсових, 
дипломних і магістерських робіт; вивчення, аналіз навчально-методичної на наукової літератури, передового досвіду у сфері освіти, науки i техніки. Також методична робота викладача передбачає рецензування навчальних, навчально-методичних посібників, підручників; редагування навчальнометодичної літератури; відвідування занять 3 індивідуальної підготовки; участь/проведення інструкторсько-методичних, показових, відкритих та пробних занять, навчально-методичних зборів; контроль навчальних занять; розробку й удосконалення освітньо-професійних програм, навчальних планів, програм навчальних дисциплін та робочих програм.

Наукова діяльність здійснюється шляхом проведення наукових досліджень i розробок, створення та впровадження нових конкурентоспроможних технологій, видів техніки, матеріалів тощо. Вона також передбачає написання наукових робіт (дисертацій на здобуття наукових ступенів доктора філософії й доктора наук, монографій, статей, тез доповідей на конференціях, симпозіумах, семінарах); участь у роботі міжнародних та всеукраїнських науково-практичних, науково-методичних, міжвідомчих конференцій, семінарів, симпозіумів, підготовку доповідей; узагальнення результатів наукових конференцій; роботу у спеціалізованих вчених радах у якості голови, ученого секретаря, члена ради; рецензування дисертаційних робіт, інших наукових робіт, підготовку відгуків на автореферати, авторські заявки та винаходи; підготовку звіту 3 наукової (науково-технічної) діяльності; роботу у складі редакційних колегій наукових журналів; керівництво науково-дослідними роботами та науковими роботами (проектами) слухачів (курсантів); здійснення філологічної експертизи текстів авторефератів дисертацій; роботу у складі оргкомітетів наукових конференцій, симпозіумів, семінарів тощо.

Організаційна робота викладача ВВНЗ містить у собі декілька розділів, а саме: організаційно-методична, виховна, спортивна, міжнародна діяльність.

Організаиійно-методична робота передбачає підготовку організаційних матеріалів, проектів рішень та участь у проведенні засідань кафедри, ради інституту (факультету), вченої ради інституту (факультету), університету, науково-методичної ради університету, роботу у предметнометодичних комісіях кафедр, роботу в комісіях, радах, робочих групах Міністерства оборони України.

Виховну діяльність викладач здійснює як у процесі навчання, використовуючи потенційні можливості навчальних дисциплін, так і в позанавчальний час, під час годин самостійної підготовки. Він реалізує іiі через бесіди, співбесіди, кураторську роботу, роботу в гуртожитках, проведення свят тощо. Але тут же для викладача важливо не забувати про власний приклад - як зразок для наслідування.

Виховна робота містить в собі організаційні, морально-психологічні, педагогічні, інформаційні, культурно-просвітницькі та військово-соціальні заходи, що проводяться 3 метою формування у слухачів (курсантів, 
студентів) морально-психологічних якостей, необхідних для військової служби, готовності виконувати завдання в умовах бойових дій на фоні високої емоційної напруженості [7].

Спортивна діяльність передбачає заняття з фізичної підготовки, участь у спортивних заходах, їх організацію.

Міжнародну роботу викладач реалізує через: участь у міжнародних освітніх та наукових програмах; створення спільних освітніх i наукових програм 3 іноземними вищими навчальними закладами, науковими установами, організаціями; проведення спільних наукових досліджень; організацію міжнародних конференцій, симпозіумів, конгресів та інших заходів; спільну видавничу діяльність; відрядження закордон для науковопедагогічної (педагогічної) та наукової роботи відповідно до міжнародних договорів України, а також договорів між такими ВНЗ та іноземними партнерами; залучення науково-педагогічних (педагогічних), наукових працівників іноземних ВНЗ для участі в науково-педагогічній (педагогічній), науковій роботі у ВНЗ України [7].

У процесі педагогічної діяльності важливого значення набуває готовність викладача до неї та іiі продуктивність. Нами було виділено такі рівні готовності викладача ВВНЗ до педагогічної діяльності, як:

- penродуктивний - педагог, нічого не змінюючи, викладає матеріал із підручників, посібників, курсів лекцій, тобто відтворює прочитане;

- конструктивний - викладач будує самостійно лекцію, використовуючи різні джерела інформації (підручники, посібники, інтернет), компонує матеріал, створює так звану конструкцію;

- творчий - видозміни, авторське бачення змісту, внесення власних визначень, схем, створення чогось нового, на основі власних досліджень, упровадження результатів власних досліджень.

Продуктивність діяльності викладача ВВНЗ являє собою результативність діяльності науково-педагогічного чи наукового працівника, що характеризується кількісними та якісними показниками і засвідчує його здатність виконувати навчальну, методичну, наукову й організаційну роботу. Наприклад, фактичні витрати часу на підготовку до занять, рівень оволодіння слухачем викладеним матеріалом, якість виконання ним пропонованих завдань, ефективність використання певних ресурсів, терміни виконання роботи, кількість опублікованих науково-педагогічним чи науковим працівником статей та інших навально-методичних i наукових робіт, зацікавленість слухача у вивченні певної дисципліни тощо.

Нами виділено такі рівні продуктивності діяльності викладача ВВНЗ, як: мінімальний, нормативний, еталонний.

Мінімальний рівень може свідчити про незацікавленість педагога в результатах власної праці, низький рівень професійної підготовки, недостатню обізнаність у дисциплінах, що ним викладаються, неврахування особливостей аудиторії, з якою працює, неправильний підбір методів і засобів навчання та виховання. 
Нормативний рівень продуктивності характеризується достатнім рівнем знань, умінь і навичок слухачів, оволодіння певною дисципліною, розумінням можливостей застосування отриманих знань у професійній діяльності, доцільним використанням викладачем методів і засобів навчання та виховання.

Еталонний рівень свідчить про високий рівень підготовленості слухача 3 певної дисципліни, використання ним отриманих знань для самовдосконалення, саморозвитку й самореалізації, творчий підхід педагога до виконуваної діяльності.

За даними Н. Кузьміної, вершинних рівнів продуктивності в освіті досягають від 3,5 \% до 20 \% фахівців, які відчувають потребу в оволодінні майстерністю. Вони за більш короткий час, ніж інші, опановують мистецтво вирішувати складні спеціальні та професійні завдання, вивчають різноманітні педагогічні ситуації, формулюють і вирішують принципово нові завдання, створюють нові «продукти».

Для досягнення і підтримування еталонного рівня продуктивності своєї діяльності викладачу необхідно постійно аналізувати власну діяльність, контролювати іiі результати, своєчасно вносити корективи, вивчати фактори, що сприяють і перешкоджають досягненню результативності, шукати нові шляхи професійного самовдосконалення й реалізовувати їх на практиці.

Успішне здійснення педагогічної діяльності залежить від багатьох умов та чинників. Досліджуючи педагогічні умови професійної діяльності вчителя, В. Маркова визначила успішність професійної діяльності педагога як досягнення, що відображаються в позитивних змінах як у професійному зростанні педагога, так і в якості діяльності його учнів.

Важливе значення мають передумови успішності педагогічної діяльності, що, у свою чергу, є одним із критеріїв готовності викладача до педагогічної діяльності. До них ми відносимо такі, як: здібності (загальні та спеціальні - педагогічні), педагогічну спрямованість, професійну компетентність, розвинуту емоційно-вольову сферу особистості педагога, риси характеру, особисті якості.

Педагогічні здібності - поєднання психічних властивостей особистості, необхідних для успішного оволодіння педагогічною діяльністю. Вони $\epsilon$ складним психологічним утворенням, що у своїй структурі поєднують окремі спеціальні здібності. До них відносять такі:

- організаторські - здатність організовувати власну діяльність та діяльність слухачів (курсантів, студентів), здатність організувати й згуртувати слухацький (курсантський, студентський) колектив і спрямувати його на вирішення важливих завдань;

- проектувальні - здатність планувати власну діяльність та діяльність слухачів (курсантів, студентів), прогнозувати результати роботи, організувати співробітництво серед слухачів;

- дидактичні - здатність здійснювати дидактичне перероблення навчального матеріалу, адаптувати матеріал до рівня підготовки слухачів, 
добирати форми, методи, засоби навчання, розробляти нові методи, технології, здатність логічно й чітко викладати матеріал;

- комунікативні - здатність швидко встановити контакт зі слухачем (курсантом, студентом) і налагодити спілкування [8, 142];

- nерцеептивні - здатність адекватно сприймати особистість слухача на чуттєво-інтуїтивному рівні та розуміти його [8, 142], спостережливість здатність проникати у внутрішній світ людини, проникливість, пов'язана 3 тонким розумінням особистості людини та їі тимчасових психічних станів [3, 328];

- аналітичні - здатність до засвоєння наукових, фахових знань;

- сугестивні - здатність до емоційно-вольового впливу на слухача (курсанта, студента) [9, 15], здатність висунути вимоги й досягти їх безумовного виконання [3, 328];

- творчі - здатність до створення чогось нового, оригінального, до всестороннього аналізу педагогічних ситуацій i задач, прийняття нестандартних рішень і пошуку нестандартних підходів та способів до вирішення завдань, виконання діяльності.

Педагогічна спрямованість передбачає позитивне відношення до педагогічної діяльності, стійкий інтерес до неї, схильність займатися нею, що поступово переходить у пристрасну захопленість і життєву потребу в цій діяльності, активність та ініціативність педагога у процесі неї, бажання розвивати свої знання, уміння, навички й задовольняти таким чином матеріальні та духовні потреби. Педагогічна спрямованість особистості визначає цілі, що ставить перед собою викладач, прагнення, йому властиві, i мотиви, відповідно до яких він діє.

Професійна компетентність є інтегральним показником готовності до вирішення освітньо-виховних завдань на основі здобутих під час навчання знань, умінь, навичок, сформованої культури педагогічного спілкування, етики й естетики педагогічної діяльності [1, с. 186]. Вона дає змогу викладачу самостійно й ефективно реалізовувати цілі педагогічного процесу, передбачає єдність його теоретичної і практичної готовності до здійснення педагогічної діяльності.

Емоизї й почутmя спонукають педагога до діяльності, допомагають долати труднощі в роботі, навчанні, творчості, визначають його поведінку й постановку цілей і завдань у діяльності. Подолання перешкод та ускладнень потребує від людини вольових зусиль. Оскільки педагогічна діяльність здійснюється у процесі взаємодії викладача та слухача, кожен із яких має свої індивідуальні особливості, цінності, якості, погляди, то виникнення певних труднощів неминуче. Для постійного самовдосконалення педагогу, пошуку нових підходів, методик, обробки великого масиву інформації, побудови ефективної взаємодії зі слухачами (курсантами, студентами), дієвого вирішення педагогічних завдань необхідні вольові зусилля й прояв вольових якостей. До основних вольових якостей відносять цілеспрямованість, самостійність, рішучість, наполегливість, витримку, сміливість, мужність, 
дисциплінованість. Їх розвиток допоможе викладачу організувати власну діяльність, досягнути вершин у самовдосконаленні.

Для успіху в педагогічній діяльності наявності педагогічних здібностей та педагогічної спрямованості буде недостатньо без розвитку певних рис характеру й особистісних якостей. Тому для викладача велике значення мають такі риси характеру, як: працелюбність, організованість, зосередженість, скромність, ініціативність, самокритичність, цілеспрямованість, наполегливість, самостійність, дисциплінованість.

Особистісні якості виявляються у як фаховій, так і повсякденній діяльності, педагогічній взаємодії, спілкуванні, визначають поведінку педагога й характеризують його як особистість. До них ми відносимо такі, як: оптимізм, гуманність, емпатійність, уважність і спостережливість, гнучкість, комунікабельність, почуття гумору, витримка, стриманість і самовладання, відповідальність, упевненість, вимогливість, самокритичність.

Висновки та перспективи подальших досліджень. Педагогічна діяльність викладача вищого військового навчального закладу є творчою професійною діяльністю, спрямованою на підготовку, перепідготовку та підвищення кваліфікації компетентного військового фахівця (професіонала), здатного до саморозвитку й самовдосконалення, спроможного зайняти та відстоювати активну життєву і професійну позицію, включитися в соціальну, духовну та інші сфери життя суспільства, здібного до розвитку обороноздатності держави. Для успішного іiі здійснення педагогу необхідно у процесі підготовки враховувати всі компоненти (цільовий, змістовий, технологічний та результативний), намагатися працювати на творчому рівні, вдало поєднувати навчальну, методичну, наукову й організаційну роботу що дасть змогу досягнути еталонного рівня продуктивності, а також розвивати педагогічні здібності, педагогічну спрямованість, професійну компетентність, емоційно-вольову сферу, риси характеру, особисті якості.

Перспективами подальших досліджень $є$ вивчення умов педагогічної діяльності, складових самовдосконалення викладача ВВНЗ, що дадуть змогу йому розвивати педагогічну майстерність.

\section{ЛІТЕРАТУРА}

1. Вітченко А. О. Педагогіка вищої військової школи: [підручник] / А. О. Вітченко, В. І. Осьодло. - К. : НУОУ ім. Івана Черняховського, 2017. - 504 с.

2. Мешко Г. М. Вступ до педагогічної професії [Електронний ресурс] / Мешко Г. М. - Режим доступу://http://pidruchniki.com/11530818/pedagogika/stanovlennya_rozvitok_ pedagogichnoyi_profesiyi

3. Крутецкий В. А. Психология :[учебник] / Крутецкий В. А. - М. : Просвещение, 1986. $-336 \mathrm{c}$.

4. Кузнецов И. Н. Настольная книга практикующего педагога [Електронний pecypc] / Кузнецов И. Н. - 2008. - 291 с. - Режим доступу: //www.phantastike.com/ pedagogics/handbook/zip/.

5. Пальчевський С. С. Педагогіка [Електронний ресурс] / Пальчевський С. С. Режим доступу: http://pidruchniki.com/1720051435416/pedagogika/kultura_osvita_ukrayin skogo_vidrodzhennya. 
6. Положення про вищі військові навчальні заклади // Наказ Міністерства оборони України від 27.05.2015 № 240 [Електронний ресурс]. - Режим доступу: //http://zakon3.rada.gov.ua/laws/show/z0706-15.

7. Положення про особливості організації освітнього процесу у вищих військових навчальних закладах Міністерства оборони України та військових навчальних підрозділах вищих навчальних закладів України // Наказ від 20.07.2015№ 346.

8. Психологічна енциклопедія /О. М. Степанов. - К. : Академвидав, 2006. - 424 с.

9. Професійна діяльність і компетентність педагога. Сучасні підходи : навч.метод. посіб / укл. В. І. Петроченко. - Запоріжжя : КЗ «ЗОЦТКУМ» 3ОР, 2011. - 40 с.

\section{REFERENCES}

1. Vitchenko A. O., Os'odlo V. I. (2017) Pedagogika vishhoï vijs'kovoï shkoli [Pedagogics of the Higher Military Institution] : pidruch. - K. : NUOU im. Ivana Chernjahovs'kogo. - 504 s. (in Ukrainian).

2. Meshko G. M. Vstup do pedagogichnoï profesiï [Introduction to pedagogical profession]. [Elektronnij resurs]. - Rezhim dostupu: //http://pidruchniki.com/11530818/ pedagogika/stanovlennya_rozvitok_pedagogichnoyi_profesiyi (in Ukrainian).

3. Kruteckij V. A. (1986) Psihologija [Psychology] : ucheb. - M. : Prosveshhenie. - 336 s.

4. Kuznecov I. N. (2008) Nastol'naja kniga praktikujushhego pedagoga [Table-top book of practicing teacher]. [Elektronnij resurs]. - 291 s. - Rezhim dostupu: //www.phantastike.com/ pedagogics/handbook/zip/.

5. Pal'chevs'kij S. S. Pedagogika [Pedagogics]. [Elektronnij resurs]. - Rezhim dostupu: http://pidruchniki.com/1720051435416/pedagogika/kultura_osvita_ukrayinskogo_ vidrodzhennya (in Ukrainian).

6. Polozhennja pro vishhi vijs'kovi navchal'ni zakladi [Statement on Higher Military Educational Establishments] // Nakaz Ministerstva oboroni Ukraïni vid 27.05.2015 № 240 [Elektronnij resurs]. - Rezhim dostupu: //http://zakon3.rada.gov.ua/laws/show/z0706-15.

7. Polozhennja pro osoblivosti organizaciï osvitn'ogo procesu u vishhih vijs'kovih navchal'nih zakladah Ministerstva oboroni Ukraïni ta vijs'kovih navchal'nih pidrozdilah vishhih navchal'nih zakladiv Ukraïni [Statement on Peculiarities of the Educational Process in the Higher Military Educational Establishments of the Ministry Of Defence of Ukraine and Military Educational Units Higher Educational Establishments of Ukraine organization] // Nakaz vid 20.07.2015 № 346.

8. Stepanov O. M. (2006) Psihologichna enciklopedija [Psychological encyclopedia]. K. : Akademvidav,. - 424 s. (in Ukrainian).

9. Profesijna dijal'nist' i kompetentnist' pedagoga. Suchasni pidhodi [Professional activity and teacher's competence. Modern approaches] (2011) : navch.-metod. posib / ukl. V. I. Petrochenko. - Zaporizhzhja : KZ «ZOCTKUM»ZOR,. - 40 s. (in Ukrainian).

\section{PЕЗЮМЕ}

Ольга Красницкая, кандидат педагогических наук Национальный университет обороны Украины имени Ивана Черняховского

\section{Теоретико-методологические основы педагогической деятельности преподавателя высшего военного учебного заведения}

В статье рассмотрень теоретико-методологические основы педагогической деятельности преподавателя высшего военного учебного заведения. Обозначен исторический аспект педагогической деятельности. Показана специфика высшего 
военного учебного заведения. Обосновано понятие «педагогическая деятельность преподавателя высшего военного учебного заведения». Раскрыто структурные компоненты педагогической деятельности, направления деятельности преподавателя ВВУЗ. Определень уровни готовности преподавателя ВВУЗ $к$ педагогической деятельности (репродуктивный, конструктивный, творческий), а также уровни его производительности (минимальньй, нормативный, эталонный). Выявлень и описаньы предпосылки успешности педагогической деятельности.

Ключевые слова: педагогическая деятельность; преподаватель ВВУЗ; педагогическая деятельность преподавателя ВВУЗ; успешность педагогической деятельности; педагогические способности; педагогическая направленность; профессиональная компетентность; личностные качества.

\section{SUMMARY}

Olha Krasnytska

Candidate of Pedagogical Sciences, Ivan Cherniakhivsky National Defense University

\section{The theoretical and methodological bases of the pedagogical activity of the teacher of the higher military educational establishment}

Introduction. Development of Ukrainian stateness, current events on the territory of our country demand changes in professional training of military specialists. Thus, pedagogical activity of academic and pedagogical specialists and scientific workers of the HMEE and MEU HEE have to confirm community demands.

Purpose - to uncover the the theoretical and methodological bases of the pedagogical activity of the teacher of the higher military educational establishment.

Methods: analysis, synthesis, comparison, systematization of scientific resources.

Results. The article covers the theoretical and methodological bases of the pedagogical activity of the teacher of the higher military educational establishment. The historical aspect of the pedagogical activity was described. The peculiarity of the higher military educational establishment was shown. The structural elements of the pedagogical activity (target, content, technology, result), courses of activity of the teacher of the higher military educational establishment (educational, methodical, scientific, organizational) were identified.

Originality. The levels of readiness for pedagogical activity (reproductive, constructive, creative) of the teacher of the higher military educational establishment, as well as the levels of its productiveness (minimal, normative, standard) were defined. The prerequisites of the successfulness of the pedagogical activity (capabilities - general and specific - pedagogical, pedagogical orientation, professional competence, developed emotional and volitional spheres of the personality of the teacher, character features (hardworkingness, organization, concentration, shyness, initiative, self-criticism, purposefulness, perseverance, independence, discipline), personal qualities (optimism, humanity, empathy, attentiveness and observancy, flexibility, communication, sense of humor, patience, restrain and self-control, responsibility, confidence, strictness, self-criticism)) were identified and described.

Conclusion. The concept of the "teacher of the higher military educational establishment", which is a kind of the creative professional activity, that is aimed at training, refresher course and advanced training of the competent military specialist (professional), who can develop and improve himself, has the ability to take, defend the active existential and professional position, become a part of the social, spiritual and other spheres of the life of the society, can manage to develop the defense capacity of the state, was substantiated.

Key words: pedagogical activity; teacher of the higher military educational establishment; pedagogical activity of the teacher of the higher military educational establishment; successfulness of the pedagogical activity; pedagogical capabilities; pedagogical orientation; professional competence; personal qualities. 